\title{
Biribi: Disciplining and Punishing in the French Empire
}

On 2 July 1909, Albert Aernoult, aged 22, died at Djenan-ed-Dar (Algeria) while serving in a disciplinary corps of the French African Battalions. His parents were informed that their 'unfortunate child', whose behaviour had been unruly in the extreme, had died of a cerebral stroke. Aernoult's parents could not have imaged that almost three years later, on 11 February 1912, approximately 100,000 demonstrators would gather in Paris to follow the funeral cortège of their son, whose body was finally being repatriated. A campaign against the Bataillons d'Afrique was mounted by the anarchist CDS (Comité de défense sociale), and Aernoult's fellow disciplinaires wrote to the Ligue des Droits de l'homme to engage their support. Fighting broke out in the streets; 18 were arrested and 11 police injured. Crowds shouted 'À bas l'armée!', posters proclaimed 'À bas Biribi!', and the press talked of this being the Dreyfus affair of the workers. Historians have indeed looked back at the Aernoult affair as a 'grand moral drama' (Cerullo, 2008: 5); and as a means of gauging antimilitarism on the left before 1914 (Miller, 2003). The incident provoked a virulent display of antimilitarism in France which panicked the authorities and, it could be argued, had some influence in the promulgation of the Millerand-Berry law which went on to codify conditions for the banishment of miscreants to the by now notorious disciplinary military units. Why should the body of a French criminal who had died in Algeria have provoked such an ongoing crisis? What became

known as the Aernoult affair mobilised both the left and the right and divided France over differing visions of French identity, as had the Dreyfus affair. The scandal which had gradually emerged over the three preceding years gave a lie to the authorities' explanation of the causes of Aernoult's death. When a witness, Emile Rousset, came forward to attest that Aernoult had in fact been brutally beaten, hog-tied and left out in the heat of the sun, attention turned to the conditions of these far-flung battalions which lay beyond the public gaze. The military authorities tried to silence Rousset, and brought him before a conseil de guerre which sentenced him to five years' imprisonment. The Aernoult affair thus became not only a question of the treatment of these men in North Africa, but also one of military justice itself. The African Battalions became a prism through which class, militarism and a number of further contemporary concerns relating to social and carceral anxieties were played out.

\section{Class and contagion: dealing with degeneracy in the army}

Though disciplinary units had existed as early as 1818 , and had become concentrated in North Africa from the 1830 conquest of Algeria onwards, it was the Freycinet law of 15 July 1889 that significantly altered the army's disciplinary system.1 Article 15 of the law stipulated that those who had received a prison sentence of more than three months before undertaking their military service were to be relegated to the Bataillons d'Afrique.

This law reflects some of the major societal concerns which exercised France from the 1890s to the first decades of the twentieth century. In the wake of the humiliating defeat of 1870, and the upheavals of the early Republic, France agonised over its own identity and that of its new citizens. Defeat was conceptually linked to notions of national stagnation and decadence, and as the embodiment of the new Republic, its male citizens came under intense scrutiny.2 A concomitant statistical rise in delinquency, and contemporary interest in new medical sciences, meant that psychology, mental and medical health were linked with ideas concerning the moral health of the citizen (see Surkis, 2006). The Republic's institutions, particularly schools, military service, army (and empire) were viewed as ways to rejuvenate and rehabilitate, and keep a check on the moral hygiene of the citizen. Commentators such as Prévost-Paradol and his later successors, such as Leroy-Beaulieu, for example, advocated an aggressive and continued overseas expansion to facilitate the return of national vigour and pride (Prévost-Paradol, 1869; Leroy-Beaulieu, 1874).

It is in the light of these concerns that the Freycinet law of 1889 was promulgated. In the debates which surrounded these considerations regarding the intersection of the military and the criminal classes, many turned to notions of contagion and contamination. A contemporary criminologist stated:

Les principes d'une grande démocratie n'exigent en aucune façon que les jeunes gens honnêtes soient souillés par le contact des souteneurs, des rôdeurs de barrières, des libérés des maisons centrales auxquels s'applique la disposition vraiment préventive de loi sur le recrutement. (Larcher, 1902: 249)

Similarly, General Brun, the Minister for War noted that 'l'épuration de nos régiments est absolument nécessaire' (Kalifa, 2009: 157); and Paul Doumer that, 'l'envoi aux Bataillons d'Afrique n'est pas une punition, c'est une préservation des autres éléments' (Journal Officiel, 1910: 2045). This was echoed even more baldly in parliamentary debates, where deputy Georges Berry stated, 'il faut séparer le bon grain de l'ivraie' (Journal Officiel, 1910: 1594, 1602). In this way, then, the Republic sought to safeguard the moral health of its citizens by the removal of the possibility of 
contagion.

The African battalions were to be units of quarantine, segregation and decontamination. While the empire held out obvious tangible benefits in terms of primary resources, strategic defensive positions and manpower, it is clear here that empire was also beneficial to France in what it could remove from the metropole's own shores. The notion that difficult or dangerous elements could be removed from the heart of the nation had become evident during earlier upheavals in the nineteenth century. The French Foreign Legion had been created in 1830 precisely to remove dangerous foreign elements from Paris, and subsequent national upheavals in 1848 and 1870 saw the same 'coup de balai' effected within the metropole and swelling the Legion's ranks. The containment of these 'dangerous' classes outside the metropole and within the empire reveals also what Charles Lucas, General Inspector of Prisons, termed, 'une politique de débarras' (Lucas, 1878 : passim). The riddance of criminals and recidivists was what Albert Sarraut had in mind when he later accused France of having exported what he described as the 'déchets' of French society to the colonies (1931: 210). This process of elimination from the metropole, he argued, posed a very serious threat to the authority of the colonising nation within the colonies themselves. Without Sarraut's hindsight, Colonel Fix argued in 1898, much as had the proponents of the creation of a French Foreign Legion, that 'Là où le climat et les fatigues dévorent les hommes, il vaut mieux sacrifier ceux des bataillons, que des conscrits tirés de France' (Fix, 1898: 362-98). Containing these dangerous classes abroad had a number of side-effects. There arose among the officers employed to oversee detainees a culture of impunity; the experience of the army's disciplinary units tended to 'deform' rather than 'form' or 'reform' men; and the attempt to relegate and expel the societal detritus effected a return of the repressed in popular culture.

\section{Discipline, and the culture of 'Biribi'}

No single location ever bore the name 'Biribi', but it became popular shorthand for and blurred the distinctions between the spectrum of disciplinary military regiments, companies and prisons which France employed in North Africa (Mac Orlan, 1933: 169). The 1890 novel by Georges Darien, which took as its title the colloquial term 'Biribi', fixed this name in the cultural imagination. Biribi and the Bataillons d'Afrique became a popular cultural signifier alongside that of the French Foreign Legion, and nourished a turn-of-the-century taste for 'les bas-fonds', a prurient cultural desire for the seedy, the marginal, the underworld, gutters and backstreets, and all that signified the opposite of 'Belle Époque', and which gathered momentum with the Naturalist movement. Darien's novel had appealed to this aspect of the public imagination, and the theme of the Bataillons d'Afrique had been picked up in other popular cultural forms including music hall, the picture press and popular theatre, most notably by Aristide Bruant's, well-known chronicler of 'les bas-fonds', who enjoyed huge success with his 1911 café-concert song, 'À Biribi', followed in a similar vein by 'Les Petits Joyeux', and 'Aux Bats d'Af'. In 1905 the leftist satirical magazine L'Assiette au beurre published an entire issue of Bernard Naudin's drawings representing Biribi and its men.3 Periodicals such as Police Magazine, Détective and Police Hebdo frequently featured photographic reportages on the 'Bats d'Af' and Biribi. These publications tended to sensationalise Biribi: they focused on instances of torture, assassination, suicide and mutilation. They were also interested in the character of the detainees, their physicality and the penitentiary culture of Biribi, with its argot and customs. The particular culture of tattooing at Biribi became (and still is) a popular spectacle. Thus, in popular culture, Biribi and the disciplinary units functioned as an imaginative elsewhere - a repository where anxieties could be located, distanced and contained. It acted as the recipient of projected metropolitan anxieties: the bas-fonds of contemporary French society were displaced onto empire, where seemingly they appeared more distant and containable.

While, as previously stated, no single place ever bore the name Biribi, the word became a powerful and widely understood signifier for extreme military oppression: the arbitrary and summary punishment of irretrievable delinquency; torture, mutilation and assassination; the cruel conditions of forced labour in the unforgiving heat of a hostile North African desert. Kalifa has similarly argued that 'Biribi' might best be understood as a disciplinary and penitentiary 'archipelago', consisting of work or construction sites, permanent camps, itinerant camps and prisons (Kalifa, 2009). Its geography closely followed that of colonialism's advance through North Africa, and its 'residents' accomplished much of the work of mise en valeur: their forced labour built road and rail networks, fortifications, ports, mines and quarries.

Biribi shared some of the qualities of the darker side of the settler's colonial experience: it signified, exile, desperation, le cafard, suffering in a strange land. In reality, Biribi exposed the dark 
underbelly of the colonial effort: deportations, exploitation, forced labour and violence. At its height, 10-15,000 men a year passed through Biribi. Its long affiliation with the colonial enterprise meant that it was not until the period of decolonisation that Biribi disappeared. Between 1830 and the end of the 1960s around 800,000 men passed through Biribi. France's North African colonies had become the supreme exile for the 'classes dangereuses'.

Conditions were hard and uncompromising: back-breaking work in extreme conditions of both heat and cold in the desert of North Africa. Medical reports of the period detailed the lengths to which men would go to escape punishment or the harshness of the work, or to improve their lot. In a practice which was known in the local argot as 'maquillage': the men would cut off their fingers, deform their limbs, burn their eyes, feign paralysis or epilepsy, or even tuberculosis by cutting their gums and spitting blood; they would employ a variety of imaginative means to give the impression of illness (s'inoculer), rubbing their skin with plants to give themselves pustules, using bay leaves to give the impression of jaundice, rubbing tobacco in their eyes to give themselves conjunctivitis (Jude, 1907: 101-2).

What made Biribi unique, however, was the culture of extreme and institutionalised violence and punishment that was cultivated. For investigative journalist Albert Londres, for instance, Biribi was a 'monstre' the epitome of 'l'éternelle méchanceté de la race humaine'. One of the principles of the institution was 'le relèvement par le travail', but this was achieved 'à coups de botte' (Londres, 1924: 27, 11, 55). Londres details some of the abuses suffered by the men in Biribi: they were deprived of food and water, suffered physical abuses akin to torture, there were regular assaults and murders. The authorities turned a blind eye to abuses perpetrated between the men, and were frequently perpetrators themselves: deaths were often blamed on other factors (as in the case of Aernoult), and medical treatment was frequently withheld. Military justice was summary, and officers, resentful of their lot and their conditions, found an outlet for their own miseries by inflicting misery on their inmates. The cruelty of the officers was also linked to colonialism. Officers, or chaouchs as they were known, were perceived to be infected with the sense of superiority which afflicted the coloniser, and their location in Africa exacerbated their tendency to view themselves as distanced from higher authorities, thereby cultivating a culture of permissive cruelty and impunity.

The conditions and culture of Biribi gave rise to interesting phenomena which fascinated and appalled certain medical doctors stationed with the African battalions, who have left reports which document the peculiar environment and the ways in which men sought to navigate their existence once trapped in its disciplinary jaws. For example, the practice of tattooing became widespread throughout the French army during the nineteenth century. Its development at Biribi was, however, spectacular. According to the report of Dr René Jude, (Médecin Aide-Major de 1ère Classe aux Hôpitaux de Tunisie) eight out of ten inmates at Foum Tatouine were tattooed. It has been estimated that between 70 and 100 per cent of men returned from the 'Bat d'Af' with tattoos (Pierrat and Guillon, 2004: 44). As Feriel Ben Mahmoud has noted, 'Biribi a représenté une véritable école du tatouage' (Ben Mahmoud, 2005: 79) Alexandre Lacassagne (1843-1924), criminologist and professor of legal medicine at the University of Lyon, made of tattooing a medico-legal question, publishing an early treatise which contributed to his growing stature as France's first criminal anthropologist. While stationed as a medical doctor with the 2nd African battalion in Médéa, Algeria, Lacassagne collected around 2000 samples of tattoos from 550 subjects. He traced images direct from the skin and reproduced them in colour and with annotations. Lacassagne viewed tattoos as a forensic means of deciphering the psychology and morality of the tattooed: their everyday thoughts, images dear to them, intimate often unspoken memories, their plans for vengeance. In Les Tatouages: Étude anthropologique et medico-légale published in 1881, Lacassagne reproduced a selection from his collection with a more extended commentary. He noted that tattooing was one of the principal characteristics of delinquents. For the inmates, tattoos were symbols of revolt, and markers of their exclusion from mainstream society. The practice of 'la Bouzille', as it was known, symbolised both honour and courage, but also despair at ever being able to leave the hell of Biribi. The extent of the tattooing also meant that the detainee's body functioned as a map of his journey and his criminality, a sort of 'carte d'identité du bagnard' (Pierrat and Guillon, 2004: 80). The most popular tattoos and slogans reveal the identificatory and ontological routes these men had adopted or had had foisted upon them: 'Tout me fais rire'; 'Vaincu non dompté'; 'Vive le vin et l'amour'; 'Malheureux traitres'; 'Mort aux sous-offs'; 'Enfants du malheur'; 'Né sous une mauvaise étoile'; 'Marche ou crève'. What Lacassagne was to term these 'cicatrices parlantes', point to the physical and existential agonies of Biribi. Lacassagne came to believe that tattoos could be compared to hieroglyphics, as there are figurative, symbolic and indeed phonetic examples of their use. Tattoos, he argued, are essentially ideographical; they are almost always an idea 
that is expressed through images and symbols (Lacassagne, 1881: 26). His study showed that the tattoos which marked the experience of Biribi, almost invariably expressed despair, resentment and a desire for vengeance.

Other medical reports and psychological case studies of those detained by doctors stationed with the battalions detail the social class and circumstances of the detainees: their family backgrounds, criminal history, educational non-achievements, etc. The reports showed: 'Même dislocation familiale, même milieu pauvre et médiocre, même éducation raté, même instruction sommaire, même manque de profession ou nullité de profession (Combe, 1912).

René Jude, an army medical doctor posted to Tunisia, and the author of a 1907 book on the Batallions d'Afrique qualified all the men as 'degenerates' (Jude, 1907: 53) and devised six categories to classify them. For Jude, two-thirds of the men were 'dégénérés moyen' and according to his portrait suffered from one or more of the following deprivations, ailments, or psychological conditions or traits: alcoholism, alcoholic parents, poverty, passivity, pathological inability to take decisions, little schooling, sexual perversion, given to theft, vagrancy and gangs, mental debility, broken family; given to excess and violence, profound gaps in judgement and morality, impulsive and deceitful (Jude, 1907: 55-8). His study of 65 men attempted to link moral characteristics with physical ones. Jude found that 30 of these men were born of alcoholic parents, and 20 themselves displayed alcoholic shakes. All of the men suffered some physical abnormality.4

The predominance of homosexuality at Biribi was another widespread concern. Gérard Zwang has noted the long association of homosexuality with the military in France, but most particularly in those regiments and institutions located in the colonies: 'The choice of such a profession is made knowingly, and those who enlisted in the Legion, the African rifles, or the "Colo", were not unaware of what they were getting into' (Zwang, 1975: quoted in Aldrich, 2003: 58). These anxieties crystallised around the turn of the century, and can be related to wider concerns regarding societal decadence.

As Robert Aldrich has noted, there were widespread concerns about cross-contamination: the effects of North Africa on military morals, and the possible spread of vice to general society: 'Like the plague, sodomy might spread from the army to civilian society, from military camps to cities, from the colonies to the motherland' (Aldrich, 2003: 1975: 59). René Jude, estimated that two-thirds of the men were pederasts, and observed the high levels of the 'organisation of intimacy' between 'couples' or 'households' of the same sex ('ménages') in which tasks were clearly divided between 'men' and 'wives'. 'Mam'zelle Bibi', as this coupling was known, required men to take on particular roles: 'On est "de la pointe ou du vase", on "mord l'épaule ou la paillasse". (Mac Orlan, 1933: 153). Anxieties related to medical and moral hygiene from the late nineteenth century onwards had frequently focused on the manner in which army life tended to exacerbate anti-social or 'decadent' behaviours, such as alcoholism, recourse to prostitution, and pederasty. As Surkis has observed, military life "held out an ideal opportunity to morally form men, while simultaneously menacing to "deform" them' (Surkis, 2006: 231). For while politicians and public figures held up the value of military service as an exemplary school of virility and a veritable crucible of Republican citizenship, it was also criticised as a potential source of demoralization (Surkis, 2006: 214).

In the wake of the death of Aernoult, questions began to be posed more seriously about the conditions and culture of Biribi, and disciplinary military units more broadly. For Albert Londres, the regime represented anarchy rather than discipline, 'un désordre moral' about which the nation should feel great shame (Londres, 1924: 245-6). In the appendix to his work he addressed an open letter to the Minister for War, calling for reform of the conditions at Biribi. It should be noted that Londres does not call for the system to be dismantled entirely, but that its practices, culture and above all its officers be humanised: 'Un dresseur qui, loin de corriger les instinct sauvages de son animal, ne ferait que les aggraver ne serait lui-même qu'un incapable et stupide animal. Le sergent de Biribi est ce dresseur' (Londres, 1924: 246). Londres draws up six points which he posits as imperative 'pour arreter le scandale' (1924: 248). These focus on the improvement of medical care, the creation of an objective inspectorate and the re-education of the institutions' officers. Londres's points are motivated by the notion of rehabilitation: 'nous voulons en faire des hommes propres et honnêtes' (1924: 248).

\section{Race and human hierarchies}

The existence of Biribi clearly draws to our attention the uses of empire as a dumping-ground, but it also provoked acute concerns about intercultural contact. While empire was predicated on the innate and visible superiority of the white coloniser, it was also the place where the dregs of mainland society were dispatched in order to keep the nation pure and healthy. This provoked anxieties about the longevity and sustainability of colonial rule, which was contaminated and undermined by visible examples of men who countermanded the prevailing belief in civilisation being dispensed by a colonial aristocracy to native savages. The underclasses, degenerates and criminals which 
France exported to the colonies were tangible proof of the coloniser's inability to civilise even its own citizens.

What exacerbated anxieties was the fact that those at Biribi were often overseen and guarded by colonial troops: tirailleurs sénégalais, or zouaves. La Vie illustré carries a front cover on which a native soldier is standing over the hog-tied inmate (1902). France allowed colonised soldiers to police its own degenerates, a practice which often led to brutalities and murder, which were perceived as a vengeful exercise of power against the coloniser. The use of colonised troops to guard and discipline those attached to the 'Bats d'Af' clearly overturns the norms of hierarchical colonial society: colonial stratifications and boundaries are broken down by the presence/existence of white European criminals within a colonial context, demonstrating an instability in the colonial order, one in which the dominateur/dominé paradigm is overturned.

This, however, appears not to have been the principal concern of those who railed against this 'haine raciale'. Speaking of the British empire, Susan Thorne notes that British society tended to view race and class as similar, 'convinced by the very symmetry between representations of poor and colonised peoples, that both forms of subordination were just, both prejudices true' (Thorne, 1997: 248). Parallel perceptions and systems of oppression thus appear to have been at work in which race and class were conflated. For it was not the topsy-turvy inversion of the white/native binary which exercised commentators, it was the assault on French values and principles: on the identity of the nation itself.

De temps à autre, des groupes d'Arabes regardent, graves, passer ces hommes. Et devant l'avilissement d'Européens - de gens de la race victorieuse - quelles réflexions assaillent leurs âmes frustes de primitifs? Sur leurs faces, d'ordinaire impassibles, passe comme la palpation d'une joie ... N'est-ce pas une revanche? Car il semble que ces indigènes asservis, déchus de leur antique puissance, se disent qu'après tout, nous ne leur sommes pas si supérieurs, puisque nous apportons à châtier ceux d'entre nous qui ont commis une faute [de] la même cruauté que les incivilisés eux-mêmes ...

Et s'ils savaient! S'ils savaient que ces hommes, que ces Français si barbarement traités, menés en bétail, ne sont pas des criminels, que penseraient-ils, dans leur inflexible logique d'enfants, de notre justice - de notre Humanité? (Dhur, 1925: 12)

\section{Conclusions}

An examination of Biribi and the campaigns to reform or abolish it reveal palimpsestic layers of moral panic. Fear of contagion led to segregation, which in turn seemed to lead to further degradation. Biribi appeared to function as a penitentiary mise en abyme: those at Biribi were pénitenciers, but were also punished there. Having been punished at home, they were relegated to the 'Bat d'Af', and if they committed misdemeanours there, they were sent to Biribi, a punishment in itself, but where further punishment awaited. The system reveals layer upon layer of punishment and imprisonment, and for some there was never any escape from this abyss: hence Londres' subtitle to his work 'Dante n'avait rien vu'. Unlike the French Foreign Legion, where atonement or rehabilitation could be achieved and a new life and identity invented, in the 'Bats d'Af' and Biribi men were condemned for life. For many, a return to normal life was no longer possible. Some men argued the case to be sent to the penal colonies rather than return to normal life. They had become professional prisoners: 'Ce n'est pas à mon âge qu'on recommence une existence' (Londres, 1924: 159). The Empire played a complex role in the circuitry of punishment and delinquency: a sentence or imprisonment was followed by banishment or enforced deportation from the mainland to North Africa, or departure for the penitentiary colonies.

The empire played a complex role in the circuitry of punishment. Circuits of delinquency: imprisonment was followed by banishment or enforced deportation from the mainland, or departure for the penitentiary colonies. For Londres, this regime represented anarchy rather than discipline, a moral disorder or disarray for which the nation should feel great shame (1924: 245-6).

Social anxieties concerning contamination and degeneracy were exacerbated by Biribi. The disciplinary regime in place represented anarchy rather than discipline, and a moral disorder at the

heart of the army. Campaigns against Biribi focused on the shame it should provoke in a nation which believed it embodied the universal rights of man. The 'civilising mission' did not extend to the nation's own citizens: Biribi functioned to exclude rather than rehabilitate. It created career prisoners whose ritualised brutalisation precluded any possibility of redemptive justice. The existence of Biribi raises questions about the conflation of views of race and the lower classes: its very creation epitomises the concern over social contagion from the lower classes, and presents a case of moral panic in itself. Revelations about the brutal and brutalising conditions of these institutions, however, raised a further moral panic over national values and principles of justice and civilisation, which became all the more acute as they were played out in the empire, whose existence 
depended upon an unchanging vision of racial and moral superiority. Because by the turn of the century Jules Ferry's notion of mission civilisatrice had become central to French imperial identity, the presence of Biribi came to threaten the authority of empire as it attested to the Republic's failure to civilise elements of its own population: a failure of its internal civilising mission. Furthermore, the degenerate, criminal and transgressive character of the detainees was a very visible challenge to the widely held hierarchical racial assumptions which governed the practices of empire.

\section{Notes}

1 The existence of disciplinary military units attached to the French army dates back to the creation in 1818 of disciplinary companies (fusiliers et pionniers de discipline) by Maréchal Gouvin-Saint-Cyr. These companies were intended for undisciplined soldiers from the ranks, drunks and young conscripts who tried to avoid service through self-mutilation. After 1830, these companies were progressively moved to North Africa.

2 Decadence was originally a medical term, meaning a departure from the normal human type which would lead progressively to destruction. Such a departure could be caused by inherited disease, shattered nerves, poisoning through alcohol or indulgence in vice (Mosse, 1998: 62).

3 Bernard Naudin (1876-1946) was known as an illustrator and engraver for satirical magazines before becoming a war artist as a sergeant in the infantry in 1914. He illustrated Georges Darien's Biribi (see Cornu, 1912).

4 Jude noted ear malformations, facial asymmetry, cranial asymmetry, dental malformation, squint, crossed eyes, exaggeratedly small testicles, stuttering and stammering.

\section{References}

Aldrich R (2003) Colonialism and Homosexuality. London: Routledge.

Ben Mahmoud F (2005) Bat d'Af: La légende des mauvais garçons. Paris: Mengès.

Cerullo J (2008) The Aernoult-Rousset affair: military justice on trial in Belle Époque France. Historical

Reflections 34(2): 4-24.

Combe L (1912) Le Soldat d'Afrique. Paris: Charles Lavauzelle.

Cornu P (1912) Bernard Naudin, dessinateur et graveur. Nevers: Cahiers du Centre.

Darien G (1890) Biribi. Paris: Alfred Savine.

Dhur J (1925) Les Bagnes militaires. Paris: Librairie populaire.

Fix T (1898) Zéphyrs, disciplinaires et camisards. Revue de Paris, pp. 362-398.

Journal Officiel (1910) 25 March.

Jude R (1907) Dégénérés dans les Bataillons d'Afrique. Paris: Le Beau.

Kalifa D (2009) Biribi: Les bagnes coloniaux de l'Armée française. Paris: Perrin.

Lacassagne A (1881) Les Tatouages: Étude anthropologique et médico-légale. Paris: Baillière.

Larcher E (1902) Trois années d'études algériennes, législatives, sociales, pénitentiaires et pénales, 1899

1901. Paris: Rousseau.

Lerouy Beaulieu P (1874) De la colonisation chez les peuples modernes. Paris: Guillaumin.

Londres A (1924) Dante n'avait rien vu. Paris: Albin Michel.

Lucas C (1878) La Transportation pénale ou la politique du débarras: rapport verbal à l'occasion de la notice publiée par le ministère de la Marine sur la Guyane française et la Nouvelle-Calédonie. Orléans: Colas.

Mac Orlan P (1933) Le Bataillon de la mauvaise chance: Un civil chez le Joyeux. Paris: Éditions de France. Miller P (2003) Down but not out: the antimilitarist left in the Aernoult-Rousset Affair 1909-1912. French History 17(2): 172-85.

Mosse G (1998) The Image of Man: The Creation of Modern Masculinity. Oxford: Oxford University Press. Pierrat J and Guillon E (2004) Les Vrais, les durs, les tatoués. Paris: Larivière. Prévost-Paradol L-A (1869) La France nouvelle. Paris: Michel Lévy.

Sarraut A (1931) Grandeur et servitude coloniales. Paris: Sagittaire.

Surkis J (2006) Sexing the Citizen: Morality and Masculinity in France 1870-1920. Ithaca, NY: Cornell

University Press.

Thorne S (1997) 'The conversion of Englishmen and the conversion of the world inseparable': missionary imperialism and the language of class in early industrial Britain. In: L Soler and F Cooper (eds) Tensions of Empire: Colonial Cultures in a Bourgeois World. Berkeley: University of California Press.

La Vie illustrée (1902) 24 January.

Zwang G (1975) La Fonction érotique. Paris: Laffont. 